Fight Pictures 
The publisher gratefully acknowledges the generous support of Eric Papenfuse and Catherine Lawrence as members of the Publisher's Circle of the University of California Press Foundation. 


\title{
Fight Pictures
}

A History of Boxing and Early Cinema

\author{
DAN STREIBLE
}

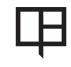

University of California Press

BERKELEY LOS ANGELES LONDON 
University of California Press, one of the most distinguished university presses in the United States, enriches lives around the world by advancing scholarship in the humanities, social sciences, and natural sciences. Its activities are supported by the UC Press Foundation and by philanthropic contributions from individuals and institutions. For more information, visit www.ucpress.edu.

University of California Press

Berkeley and Los Angeles, California

University of California Press, Ltd.

London, England

(C) 2008 by The Regents of the University of California

Library of Congress Cataloging-in-Publication Data

Streible, Dan.

Fight pictures : a history of boxing and early cinema / Dan Streible.

p. $\mathrm{cm}$.

Includes bibliographical references and index

ISBN 978-0-520-25074-I (cloth : alk. paper)-ISBN 978-0-520-25075-8 (pbk. : alk. paper)

1. Boxing films-United States-History and criticism. I. Title.

PN1995.9.B69S77 2008

791.43'6579-dc22

2007043788

Manufactured in the United States of America

$\begin{array}{llllllllll}17 & 16 & 15 & 14 & 13 & 12 & 11 & 10 & 09 & 08 \\ 10 & 9 & 8 & 7 & 6 & 5 & 4 & 3 & 2 & 1\end{array}$

This book is printed on Natures Book, which contains $50 \%$ postconsumer waste and meets the minimum requirements of ANSI/NISO z39.48-1992 (R 1997) (Permanence of Paper). 


\section{For my parents, Mama Joan \& Papa Jim}


This page intentionally left blank 